Article

\title{
Evaluating Changes in Cell-Wall Components Associated with Clubroot Resistance Using Fourier Transform Infrared Spectroscopy and RT-PCR
}

\author{
Rachid Lahlali ${ }^{1,2}$ (D), Tao Song ${ }^{3}$, Mingguang $\mathrm{Chu}^{3}$, Fengqun $\mathrm{Yu}^{3}$, Saroj Kumar ${ }^{1,4}$, \\ Chithra Karunakaran ${ }^{1}$ and Gary Peng ${ }^{3, *}$ \\ 1 Canadian Light Source, 44 Innovation Blvd, Saskatoon, SK S7N 2V3, Canada; lahlali.r@gmail.com (R.L.); \\ sarojgupta.k@gmail.com (S.K.); chithra.karunakaran@lightsource.ca (C.K.) \\ 2 Currently Department of Crop Protection, Phytopathology Unit, Ecole Nationale d'Agriculture de Meknès, \\ BP/S 40, Meknès 50001, Morocco \\ 3 Saskatoon Research and Development Centre, Agriculture and Agri-Food Canada 107 Science Place, \\ Saskatoon, SK S7N 0X2, Canada; tao.song@agr.gc.ca (T.S.); chumg@163.com (M.C.); \\ fengqun.yu@agr.gc.ca (F.Y.) \\ 4 Currently Department of Biophysics, All India Institute of Medical Sciences, New Delhi 110029, India \\ * Correspondence: gary.peng@agr.gc.ca; Tel.: +1-306-385-9410
}

Received: 18 July 2017; Accepted: 22 September 2017; Published: 26 September 2017

\begin{abstract}
Clubroot disease is a serious threat to canola production in western Canada and many parts of the world. Rcr1 is a clubroot resistance (CR) gene identified recently and its molecular mechanisms in mediating $\mathrm{CR}$ have been studied using several omics approaches. The current study aimed to characterize the biochemical changes in the cell wall of canola roots connecting to key molecular mechanisms of this CR gene identified in prior studies using Fourier transform infrared (FTIR) spectroscopy. The expression of nine genes involved in phenylpropanoid metabolism was also studied using qPCR. Between susceptible (S) and resistance (R) samples, the most notable biochemical changes were related to an increased biosynthesis of lignin and phenolics. These results were supported by the transcription data on higher expression of BrPAL1. The up-regulation of PAL is indicative of an inducible defence response conferred by Rcr1; the activation of this basal defence gene via the phenylpropanoid pathway may contribute to clubroot resistance conferred by Rcr1. The data indicate that several cell-wall components, including lignin and pectin, may play a role in defence responses against clubroot. Principal components analysis of FTIR data separated non-inoculated samples from inoculated samples, but not so much between inoculated $S$ and inoculated R samples. It is also shown that FTIR spectroscopy can be a useful tool in studying plant-pathogen interaction at cellular levels.
\end{abstract}

Keywords: Brassica napus; callose deposition; infrared spectroscopy; phytoalexins; quantitative RT-PCR

\section{Introduction}

Clubroot, caused by the obligate soil-borne pathogen Plasmodiophora brassicae Woronin, is a serious disease of Brassica crops worldwide [1] and a threat to canola (Brassica napus L.) production in western Canada [2]. An integrated approach [3] is recommended for managing the disease on canola, although host resistance is the cornerstone of the strategy. Clubroot resistance (CR) has been found from only limited sources, mainly B. rapa ssp. rapifera (turnips) and to a lesser extent B. oleracea L. [4-6]. So far, eight CR loci have been mapped to five B. rapa linkage groups [7-10], but the resistance mechanisms are generally unclear for most of these CR genes [11]. Some of the CR genes were incorporated into B. napus oilseed rape first in Europe; "Mendel" and "Tosca" were 
registered in 2000s [12], with each cultivar receiving one race-specific CR genes from a turnip cultivar. CR genes have also been incorporated into rutabaga (B. napus, ssp. napobrassica) [13], Chinese cabbage (B. rapa L.) [4,14], and canola [15]. Peng et al. [16] evaluated a wide range of Brassica germplasms and identified several highly resistant candidates against the predominant $P$. brassicae pathotype in western Canada. Further work characterized the CR gene Rcr1 in B. rapa ssp. Chinensis [11].

Single-gene resistance to clubroot is often not durable; the breakdown of resistance has been widely reported on Chinese cabbage in Japan [17] and recently on canola in Canada [18]. Pyramiding or rotating multiple $\mathrm{CR}$ genes of different modes of action may improve the durability, but the effective use of such a strategy would require the knowledge of resistance mechanisms associated with specific CR genes. Such information is generally unavailable for most of the CR genes identified. A study based on the transcriptome analysis indicated that callose deposition is associated with the resistance conferred by Rcr1 [11]. In separate studies on Arabidopsis, cell-wall constituents such as amino acids and phenylpropanoids were suggested to be related to clubroot resistance [19], while other host metabolic changes appeared to be associated with the pathogenicity of P. brassicae [20]. Many of these pathogen-induced metabolic changes, however, were suppressed in plants carrying Rcr 1 and such metabolic interference may include changes in the amount of fatty acids, phenolic or aromatic components, polysaccharides, and carbohydrates in root tissues. Some of these changes can be measured precisely with Fourier transform infrared (FTIR) spectroscopy, and when combining the data with molecular measurements during CR expression, it can be valuable information for understanding the cell-wall biochemical mechanisms associated with specific CR genes.

The FTIR spectroscopy is a powerful analytical technique capable of determining the biochemical composition of plant cells, especially for fatty acids, proteins, polysaccharides, and carbohydrates [21]. It is not known, however, whether it would identify the changes of these elements in canola roots during clubroot infection influenced by CR genes. The FTIR spectroscopy, with a spectral range from 4000 to $400 \mathrm{~cm}^{-1}$, is capable of analysing organic compounds containing $-\mathrm{OH},-\mathrm{NH}$, and $-\mathrm{CH}$ functional groups [21,22] using a small sample size, therefore minimizing potential changes in the biochemical composition caused by sample processing during traditional cytological analyses. It is a procedure that provides a snapshot of biochemical composition in plant tissues or cells at specific points under diverse environments [21-25]. FTIR can generate a spectrum based on the vibrations of bonds within functional groups that can be considered as a biochemical or metabolic "fingerprint". Based on the peak width, position, and the intensity of absorption, the configuration of molecular functional assemblies can be achieved [26-28]. FTIR may also be used for plant phenotyping based on signature biochemical elements [22], potentially complementing the selection based on genetic markers. The objective of this study was to assess the potential of using FTIR spectroscopy with quantitative PCR to identify biochemical and molecular traits associated with the clubroot resistance mediated by Rcr1, especially in relation to changes in cell wall components during the infection by P. brassicae, as suggested by the transcriptome study earlier [11].

\section{Results and Discussion}

\subsection{Biochemical Changes in the Cell Wall}

The P. brassicae inoculation caused substantial changes in the spectra of resistant (R) and susceptible (S) roots when compared to respective controls; the characteristic spectral peaks that can be assigned to distinct functional groups are presented in Table 1 and Figure 1. Apart from the intensive but non-specific stretching bands for OH $\left(3697-3098 \mathrm{~cm}^{-1}\right)$ and alkyl C-H $\left(\sim 2924 \mathrm{~cm}^{-1}\right)$ groups, the spectra showed two prominent peaks at 1655 and $1061 \mathrm{~cm}^{-1}$, which might be attributable to amide I ( $\mathrm{C}=\mathrm{O}$ stretch) and $\mathrm{C}-\mathrm{O}-\mathrm{C}$ vibrations, respectively, in cellulose (Table 1$)$. The region from 3000 to $2700 \mathrm{~cm}^{-1}$ was dominated by the $\mathrm{C}-\mathrm{H}$ stretching vibrations of $-\mathrm{CH}_{3}$, $\mathrm{CH}_{2}, \mathrm{CH}$ and $\mathrm{CHO}$ functional groups [29,30]. Some of the fingerprint regions showed intense peaks for carbonyl compound $\mathrm{C}=\mathrm{O}$ groups $\left(1740 \mathrm{~cm}^{-1}\right)$, amide II $(\mathrm{N}-\mathrm{H}$ stretch $)$ and aromatic 
skeletal vibrations $\left(1548 \mathrm{~cm}^{-1}\right)$, methoxyphenolic substitutions in the aromatic unit of lignin $\left(1518 \mathrm{~cm}^{-1}\right)$, and $-\mathrm{C}-\mathrm{O} /-\mathrm{C}=\mathrm{O}$ or $\mathrm{P}-\mathrm{O}$ stretching $\left(1151 \mathrm{~cm}^{-1}\right)$, which is characteristic of carbohydrates, hemicelluloses, and phosphate [26,31-33].

Table 1. The assignment of main functional groups based on Fourier transform infrared (FTIR) spectra $[21,26,32,33]$ of susceptible $(S)$ and resistant (R) root samples. Wave numbers presented in the table are the mean of vibrational range.

\begin{tabular}{ccc}
\hline Wavenumber $\left(\mathbf{c m}^{-\mathbf{1}}\right)$ & Absorption Peak Location and Assignment & Components \\
\hline 3410 & $-\mathrm{OH}$ groups, $\mathrm{NH}$ stretching & Proteins (Amide A) \\
2927 & $\mathrm{C}-\mathrm{H}$ stretch (asym.) of $\mathrm{CH}_{2}$ & Lipid acyl chains \\
1740 & $\mathrm{C}=\mathrm{O}$ stretching: carbonyl ester compounds & Pectin \\
1650 & $-\mathrm{C}=\mathrm{O}-$ and $-\mathrm{C}=\mathrm{N}-$ stretching & Proteins (Amide I) \\
1548 & $\mathrm{~N}-\mathrm{H}$ bending and $\mathrm{C}-\mathrm{N}$ stretching & Proteins (Amide II) \\
1518 & $\mathrm{CH}_{2}$ and $\mathrm{CH}_{3}$ methylene chain stretching & Lignin \\
1246 & $\mathrm{C}-\mathrm{O},-\mathrm{CH}_{2}$ - stretching and bending, P-O stretching & Hemicellulose \\
1151 & $\mathrm{C}-\mathrm{O}-\mathrm{C}$ asymmetric stretching, $\mathrm{PO}_{2}$ stretching & Cellulose \\
1061 & $\mathrm{C}-\mathrm{O}-\mathrm{C}$ symmetric stretching & Cellulose \\
\hline
\end{tabular}

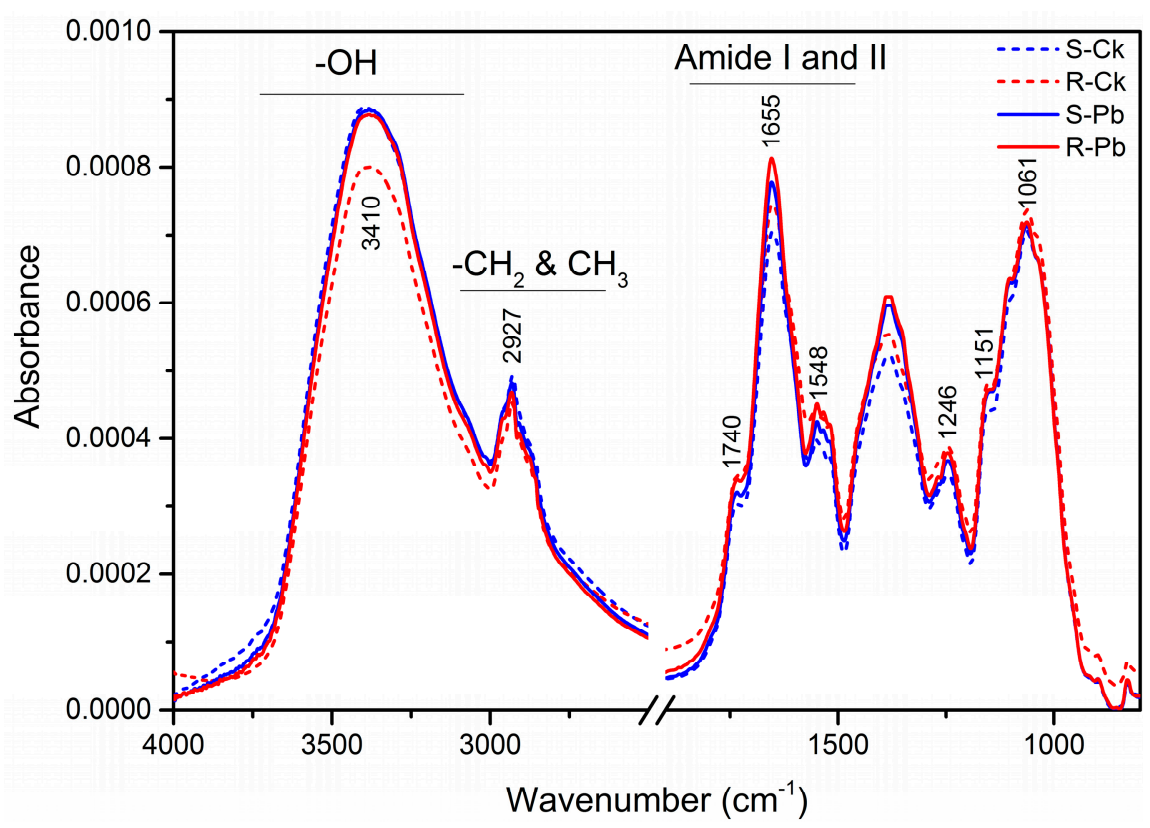

Figure 1. Mean infrared spectra of non-inoculated (Ck) and inoculated (Pb) samples of susceptible (S) and resistant (R) plants. Data were averaged over 20 pellets (10 per replicate) for each treatment.

The examination of secondary derivatives of respective absorbance also identified the differences among root samples (Figures $2-4$ ). There was a decrease in band intensity in inoculated $R$ and $S$ samples at $2961,2924,2873$, and $2853 \mathrm{~cm}^{-1}$ relative to the respective non-inoculated controls, whereas the bands at 2910 and $2845 \mathrm{~cm}^{-1}$ increased (dips) in intensity in inoculated samples (Figure 2). This increase in two methylene bands may be used as markers for clubroot infection, and these changes seem to be correlated with a change in carbonyl esters at $1640 \mathrm{~cm}^{-1}$ (Figure 3) and a shift in the methylene bending vibration at $1475-1445 \mathrm{~cm}^{-1}$ (Figure 4), Based on the integrated absorption bands, phenolic groups (1580-1530 $\left.\mathrm{cm}^{-1}\right)$, lignin $\left(1525-1505 \mathrm{~cm}^{-1}\right)$, and pectin $\left(840-815 \mathrm{~cm}^{-1}\right)$ increased substantially in inoculated $\mathrm{R}$ samples relative to those in $\mathrm{S}$ samples (Tables 2 and 3). Since the band in the amide I region can provide further insights into the protein secondary structure $[34,35]$, we assessed the specific changes in secondary proteins and observed that the percentage of $\beta$-sheet was significantly higher in inoculated $\mathrm{R}$ than that in inoculated $\mathrm{S}$ samples (Table 4). This result may be of importance due to the many amino acids captured in this band $\left(1628 \mathrm{~cm}^{-1}\right)$, notably those implicated in resistance 
responses to plant diseases, especially L-phenylalanine; this amino acid is the key precursor for host defence metabolites produced via the phenylpropanoid and lignin pathways [36-38]. Lignin and phenolics (1620-1580 $\left.\mathrm{cm}^{-1}\right)$, as well as the carbonyl ester group $\left(1740 \mathrm{~cm}^{-1}\right)$ were substantially higher in inoculated $\mathrm{R}$ than inoculated $\mathrm{S}$ samples (Tables 2 and 3 ) and this suggests that these compounds may contribute to clubroot resistance conferred by Rcr1.A small increase was observed in the symmetric and asymmetric stretching vibrations of $\mathrm{PO}_{2}{ }^{-}$phosphodiestersand $\mathrm{C}-\mathrm{O}$ stretching vibrations with inoculated $S$ or R samples (Table 2). The 1200 to $800 \mathrm{~cm}^{-1}$ region is characteristic for the bands associated with C-C, C-O-C, and C-O-P stretching vibrations of polysaccharides $[28,39,40]$.

PCA was performed on FTIR data from the lipid $\left(3100-2800 \mathrm{~cm}^{-1}\right)$ and fingerprint $(1800$ $800 \mathrm{~cm}^{-1}$ ) regions to better understand the biochemical differences among samples. The results (PC-1 and PC-2) separated inoculated from non-inoculated root samples (59-97\%), but did not differentiate between the inoculated $\mathrm{R}$ and $\mathrm{S}$ effectively.

This is the first report on using FTIR spectroscopy to understand plant-pathogen interaction based on changes in cell-wall components in conjunction with molecular traits linked to disease resistance. The study identified several characteristic bands associated with clubroot resistance that involve proteins, lignin, and phenolics (Table S1). These elements have been used in phenotyping plants [41,42], especially for the chemical profiling of the cell wall in response to biotic (fungal infection) and abiotic stresses [21,43,44]. Using the same approach, Lahlali et al. [45] identified chemical changes, particularly in lignin, cellulose, and hemicellulose, associated with wheat spikes infected by Fusarium graminearum. Martin et al. [46] used chemical fingerprints to discriminate disease resistant and susceptible clones of Ulmus pumila, and found spectral bands uniquely linked to two phenotypic groups $[43,46]$. Prior studies have used FTIR spectroscopy in combination with multivariate analysis to determine the changes in the metabolic patterns of tree roots before and after the infection by Phytophthora cinnanoni [47] or P. Ramorum [48]. This approach is considered simple, rapid, and cost-effective for high-throughput phenotyping as compared to other laboratory-extraction techniques $[49,50]$ or molecular sequencing techniques [51].

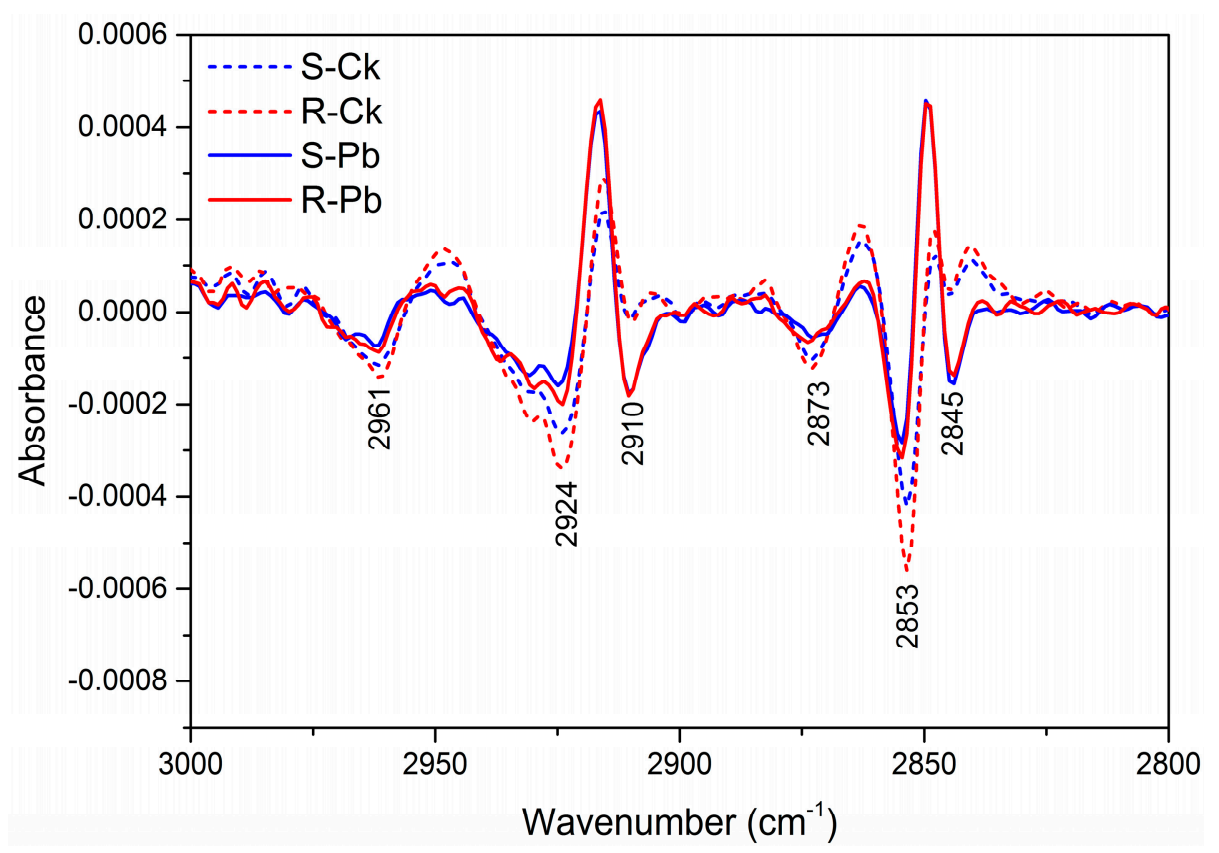

Figure 2. Absorbance of second derivatives in the lipid region $\left(3000-2800 \mathrm{~cm}^{-1}\right)$ for non-inoculated $(\mathrm{Ck})$ and inoculated $(\mathrm{Pb})$ samples of susceptible $(\mathrm{S})$ and resistant $(\mathrm{R})$ plants. Data were averaged over 20 pellets (10 per replicate) for each treatment. For secondary derivatives, dips represent the increase in chemistry; it goes in the opposite direction of spectral intensity. 


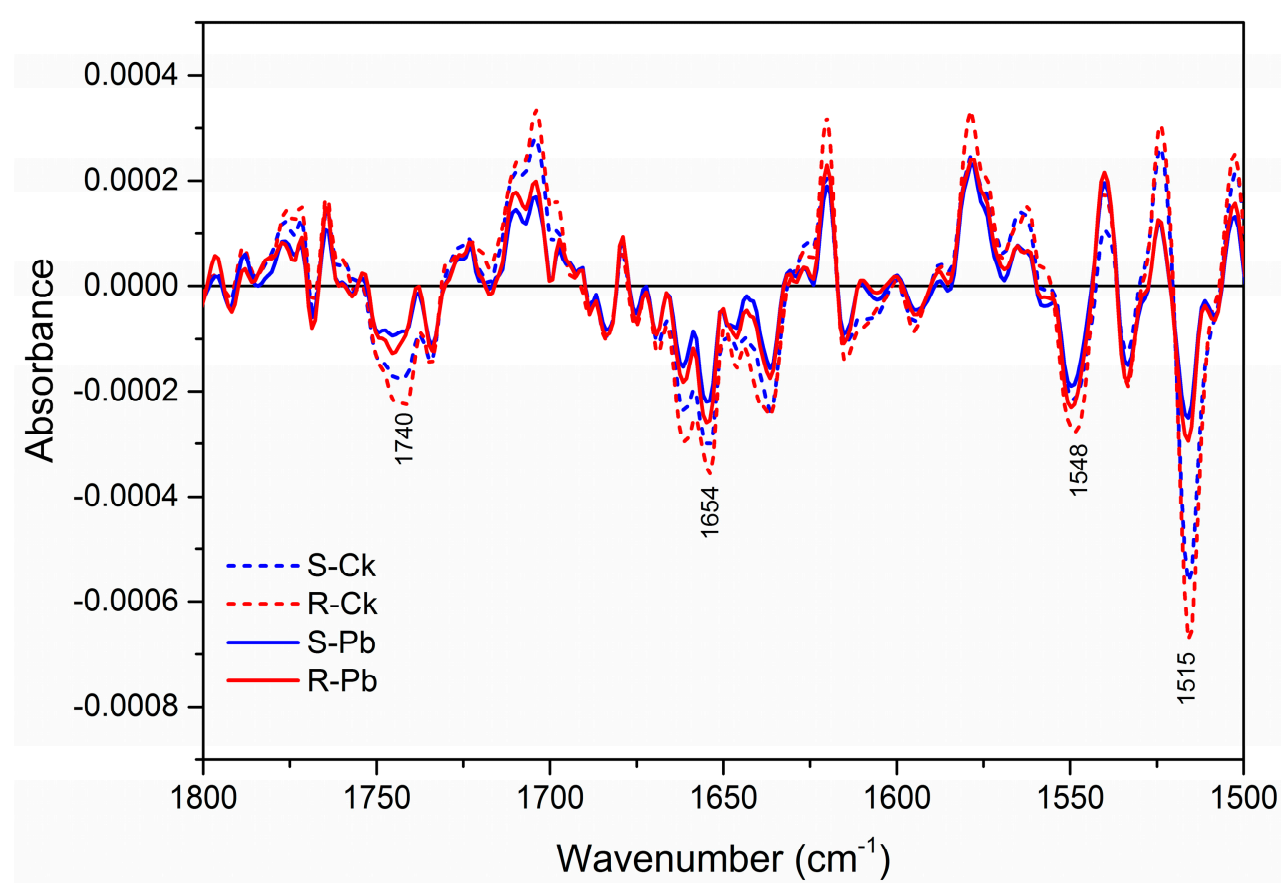

Figure 3. Absorbance of second derivatives in the fingerprint region (1800-1500 $\left.\mathrm{cm}^{-1}\right)$ between non-inoculated $(\mathrm{Ck})$ and inoculated $(\mathrm{Pb})$ root samples of susceptible $(\mathrm{S})$ and resistant $(\mathrm{R})$ canola plants. Data were averaged over 20 pellets (10 per replicate) for each treatment.

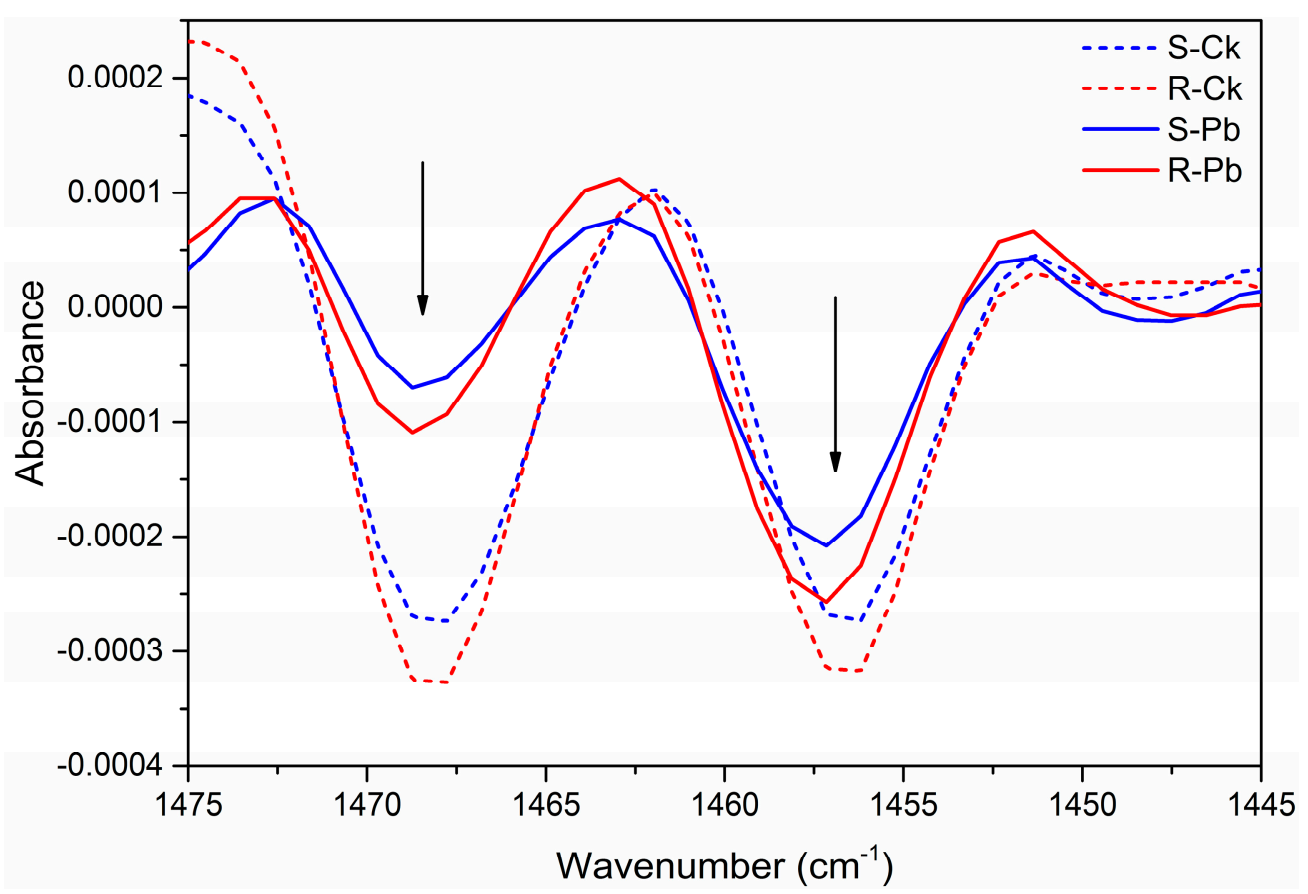

Figure 4. Absorbance of second derivatives in the fingerprint region (1500-1445 $\left.\mathrm{cm}^{-1}\right)$ between non-inoculated $(\mathrm{Ck})$ and inoculated $(\mathrm{Pb})$ root samples of susceptible $(\mathrm{S})$ and resistant $(\mathrm{R})$ canola lines. Data were averaged over 20 pellets (10 per replicate) for each treatment. Arrows indicate observable differences in chemistry between inoculated $\mathrm{R}$ and $\mathrm{S}$ samples. 
Table 2. Integrated absorption band area of $-\mathrm{OH}$ stretching, amide A (3680-3000), carbonyl ester (1760-1720 $\left.\mathrm{cm}^{-1}\right)$, amide I $\left(1700-1620 \mathrm{~cm}^{-1}\right)$, amide II $\left(1620-1580 \mathrm{~cm}^{-1}\right)$ and phenolic groups $\left(1580-1530 \mathrm{~cm}^{-1}\right)$.

\begin{tabular}{ccccccc}
\hline & Amide A & Acyl Lipids & Carbonyl Ester & Amide I & Amide II & Phenolic Ring \\
\hline $\mathrm{S}-\mathrm{CK}$ & $564.0 \pm 7.4 \mathrm{a}$ & $34.7 \pm 1.5 \mathrm{ab}$ & $10.8 \pm 0.5 \mathrm{ab}$ & $61.8 \pm 1.9 \mathrm{a}$ & $14.7 \pm 0.7 \mathrm{~b}$ & $4.1 \pm 0.2 \mathrm{a}$ \\
$\mathrm{S}-\mathrm{Pb}$ & $620.3 \pm 8.7 \mathrm{c}$ & $36.1 \pm 1.1 \mathrm{~b}$ & $10.7 \pm 0.5 \mathrm{ab}$ & $68.6 \pm 1.7 \mathrm{c}$ & $15.2 \pm 0.7 \mathrm{~b}$ & $5.3 \pm 0.3 \mathrm{~b}$ \\
$\mathrm{R}-\mathrm{CK}$ & $597.0 \pm 8.8 \mathrm{~b}$ & $35.6 \pm 1.1 \mathrm{ab}$ & $9.9 \pm 0.5 \mathrm{a}$ & $63.8 \pm 1.6 \mathrm{ab}$ & $15.0 \pm 0.6 \mathrm{~b}$ & $4.1 \pm 0.2 \mathrm{a}$ \\
$\mathrm{R}-\mathrm{Pb}$ & $550.9 \pm 9.5 \mathrm{a}$ & $33.7 \pm 1.1 \mathrm{a}$ & $11.0 \pm 0.4 \mathrm{~b}$ & $65.7 \pm 1.9 \mathrm{bc}$ & $13.6 \pm 0.5 \mathrm{a}$ & $6.1 \pm 0.2 \mathrm{c}$ \\
\hline
\end{tabular}

R: Resistant canola line carrying Rcr1; S: Susceptible line without Rcr1; Ck: non-inoculated; Pb: Inoculated with Plasmodiophora brassicae. Means in the same column followed by the same letter do not differ (Least significant difference (LSD), $p=0.05$ ).

Table 3. Integrated absorption band area for lignin $\left(1525-1505 \mathrm{~cm}^{-1}\right)$, hemicellulose $\left(1275-1215 \mathrm{~cm}^{-1}\right)$, cellulose (1090-1043 $\left.\mathrm{cm}^{-1}\right)$, and ring vibration of pectin $\left(840-815 \mathrm{~cm}^{-1}\right)$ insusceptible (S) and resistant (R) samples under non-inoculated $(\mathrm{Ck})$ and inoculated $(\mathrm{Pb})$ conditions.

\begin{tabular}{ccccc}
\hline & Lignin & Hemicellulose & Cellulose & Pectin \\
\hline S-CK & $3.3 \pm 0.2 \mathrm{a}$ & $8.3 \pm 0.2 \mathrm{a}$ & $62.8 \pm 2.8 \mathrm{~b}$ & $0.8 \pm 0.0 \mathrm{a}$ \\
S-PK & $3.7 \pm 0.1 \mathrm{~b}$ & $8.7 \pm 0.2 \mathrm{~b}$ & $60.7 \pm 1.5 \mathrm{~b}$ & $0.8 \pm 0.1 \mathrm{a}$ \\
R-CK & $3.2 \pm 0.1 \mathrm{a}$ & $8.2 \pm 0.2 \mathrm{a}$ & $64.0 \pm 2.4 \mathrm{~b}$ & $0.8 \pm 0.1 \mathrm{a}$ \\
R-Pb & $4.0 \pm 0.1 \mathrm{c}$ & $8.7 \pm 0.2 \mathrm{~b}$ & $55.3 \pm 2.5 \mathrm{a}$ & $0.9 \pm 0.1 \mathrm{~b}$ \\
\hline
\end{tabular}

R: Resistant canola line carrying Rcr1; S: Susceptible line without Rcr1; Ck: non-inoculated; Pb: Inoculated with $P$. brassicae. Means in the same column followed by the same letter do not differ (LSD, $p=0.05)$.

Table 4. The percentage of secondary protein structures found in resistant (R) and susceptible (S) samples $(n=20)$.

\begin{tabular}{|c|c|c|c|c|}
\hline & \multicolumn{2}{|c|}{ Non-Inoculated (Ck) } & \multicolumn{2}{|c|}{ Inoculated $(\mathrm{Pb})$} \\
\hline & $\mathrm{S}$ & $\mathbf{R}$ & 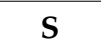 & $\mathbf{R}$ \\
\hline$\beta$-sheet (PAL) ${ }^{1}$ & $46.4 c^{2}$ & $44.2 \mathrm{~b}$ & $43.5 \mathrm{a}$ & $48.3 d$ \\
\hline$\alpha$-helices & $24.2 \mathrm{c}$ & $22.0 \mathrm{~b}$ & $26.0 \mathrm{~d}$ & $21.5 \mathrm{a}$ \\
\hline Others & $29.5 a$ & $33.8 \mathrm{~d}$ & $30.4 \mathrm{c}$ & $30.2 b$ \\
\hline
\end{tabular}

${ }^{1}$ PAL: phenylalanine ammonia lyase; ${ }^{2}$ Means in the same row followed by the same letter do not differ (LSD, $p=0.05)$.

\subsection{Transcription of Cell-Wall and Lignin-Related Genes}

Phenylpropanoids are involved commonly in plant defence responses [36], with lignin being induced as a physical barrier to infection [52]. L-Phenylalanine ammonia-lyase (PAL) is the entry-point enzyme in the phenylpropanoid pathway that can be induced by pathogens [41]; PAL is activated normally by an increased amount of reactive oxygen species (ROS), and is the key regulator in the phenylpropanoid pathway [53]. The FTIR results showed higher band absorption at $1720-1740 \mathrm{~cm}^{-1}$ for inoculated samples relative to that of non-inoculated controls (Figure 3), which is indicative of the oxidative stress associated with an increased ROS [34]. This shift in absorption intensity may be a by-product of lipid peroxidation caused also by oxidative stresses [34].

To better understand these biochemical changes, the expression of nine genes encoded for PAL biosynthesis and other cell-wall components was measured using qPCR. The gene BrPAL1 showed substantially increased activity in root samples carrying Rcr1 relative to that without the $\mathrm{CR}$ gene (Figure 5). The inoculation enhanced the expression of most genes involved in lignin biosynthesis, but the change was more pronounced with BrPAL1 in roots carrying Rcr1, possibly increasing the lignification of the cell wall in these roots via the upregulation of lignin biosynthesis genes, especially BrPAL1. Zhao et al. [54] determined that lignin biosynthesis genes are upregulated with higher amounts of endogenous plant hormones, such as gibberellins. It is therefore possible that 
the regulation of lignin pathway by Rcr 1 can initially be through the activation of phenylpropanoid pathway, and this notion is supported by the result based on global transcriptome analysis that showed the involvement of cell-wall components in the clubroot resistance mediated by Rcr1 [11]. The current transcript study was used to verify FTIR results by quantifying the expression of genes involved in lignin biosynthesis or cell wall synthesis/modification linked to resistance responses. The gene encoded for xyloglucanendo-transglycosylate $(\mathrm{BrXTH})$ was down-regulated in inoculated samples (Figure 5). BrXTH can stimulate cell division, elongation, and plant growth [55,56], due partially to the accumulation of total Indole-3-acetic acid pool [55], but it does not appear that this event is strongly related to clubroot resistance/susceptibility. The key observation is likely the strong upregulation of BrPAL1, which encodes enzymes for the early biosynthesis of lignin. We have previously reported the importance of PAL in biocontrol of clubroot by several microbial agents, including Bacillus subtilis, Heteroconium cheatospira and Colonosthys rosea [57-59]. BrPAL2, Br4CL, BrCCR and BrGST showed slightly increased activities in inoculated $S$ relatively to R samples (Figure 5). The BrGST is a family of multifunctional proteins encoding a family of genes ubiquitously found in bacteria, fungi, animals, and plants [60], and the expression of BrGST is commonly influenced by developmental processes, hormones, abiotic, and biotic stresses [61]. The slight up-regulation of these genes in inoculated $S$ samples may suggest their involvement in infection and susceptibility.
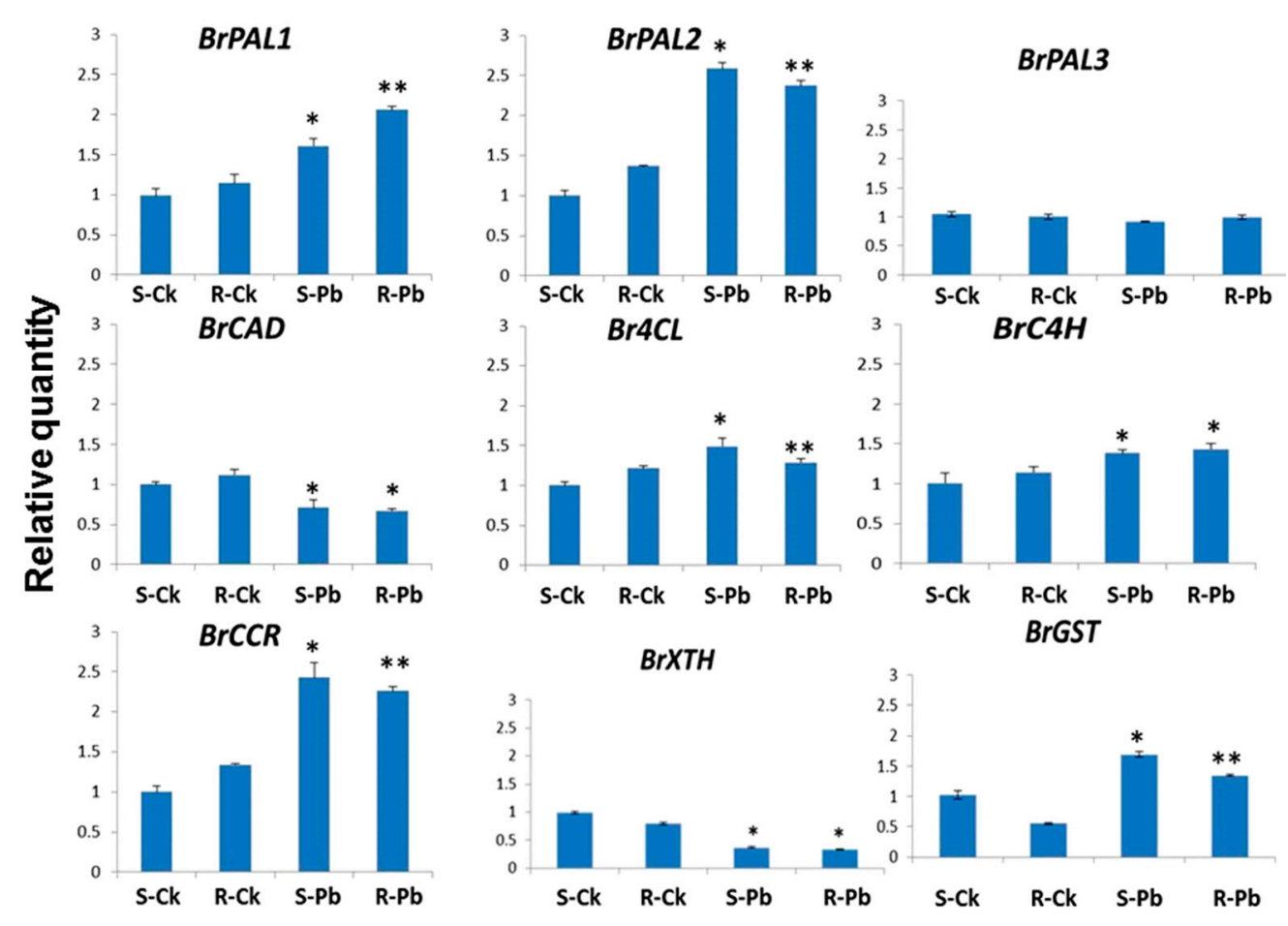

Figure 5. Expression of genes encoded for lignin biosynthesis [Phenylalanine ammonialyase (BrPAL1, BrPAL2 and BrPAL3), 4-coumarate (CoA ligase-Br4CL and cinnamate-4-hydroxylase- $B r C 4 H$ ), hydroxycinnamoyl (cinnamyl alcohol dehydrogenase- $B r C A D$ and cinnamoyl-CoA reductase- $B r C C R$ ) and cell-wall component (Glutathione-S-transferase-BrGST and Xyloglucanendo-transglycosylate- $\mathrm{BrXTH}$ )] in non-inoculated (S-Ck \& R-Ck) and inoculated (S-Pb \& R-Pb) susceptible (S) and resistant (R) root samples. Data were averaged over 6 replicates ( 3 technical $\times 2$ biological replicates). *: Significantly higher or lower against the corresponding non-inoculated control $(p<0.05)$; ${ }^{* *}$ : Significantly higher or lower against the inoculated susceptible $(\mathrm{S}-\mathrm{Pb})$ samples $(p<0.05)$.

The FTIR and qPCR analyses showed a connection between cell-wall strengthening and the up-regulation of BrPAL1 mediated by Rcr1, and these mechanisms together contribute probably to clubroot resistance. Previous studies have attempted to define the major PAL peaks in aqueous 
solutions in the $1800-800 \mathrm{~cm}^{-1}$ region, with bands reported at $1628,1583,1528,1448$, and $1408 \mathrm{~cm}^{-1}$ as predominant peaks [62]. Coupled with a significant increase in the content of $\beta$-sheet $\left(1628 \mathrm{~cm}^{-1}\right)$ and bands encoding for phenolic and aromatic rings $\left(1580-1215 \mathrm{~cm}^{-1}\right)$, data from this study support the notion that PAL biosynthesis plays a role in plants carrying Rcr1 in response to clubroot infection. Based on the biophysical and molecular analyses, it is further suggested that the activation of lignin and phenylpropanoid pathways is one of the mechanisms for clubroot resistance as conferred by Rcr1. Due to the complexity of the chemical composition in root tissues, FTIR data are usually considered qualitative rather than quantitative, which may allow to establish a pattern trend for compositional changes in plant cell wall under biotic and abiotic stresses [21]. Thus, caution is needed when interpreting FTIR data under different circumstances due to the sensitivity of technique; the results may be applicable only to specific conditions.

An integrated approach is required for clubroot management on canola $[11,63,64]$, although host resistance is the cornerstone. For the optimal deployment of CR genes, it is useful to understand resistance mechanisms associated with specific CR genes. Recent attempts to characterize the CR gene Rcr1 using transcriptome analysis [11] found the up-regulation of several genes involved in defence responses, including jasmonic acid/ethylene and callose deposition [11]. In this study, FTIR was used in combination with qPCR to analyse biochemical and molecular differences between $\mathrm{S}$ and $\mathrm{R}$ root samples, and identified that the PAL and lignin biosynthesis pathway are important to the clubroot resistance by this CR gene. This finding sheds further light on the resistance mechanisms of Rcr1; changes in cell-wall composition resulting from pathogen-induced lignification play a role.

Plant cell wall forms a dynamic physical barrier that often protects the cell from infection [65]. The chemical composition of cell wall, including cellulose, hemicellulose, and pectin vary among different tissues and can change during developmental, physiological, and pathological processes. The cell wall can also undergo dramatic structural and/or chemical changes under abiotic stresses [21,66], including lignification [67], callose deposition [68], protein cross-linking [69], accumulation of ROS, and phytoalexins [70]. FTIR can be a powerful tool to determine changes in the chemical composition of plant cell wall under biotic and abiotic stresses [21,34]. In the present study, infrared spectra were recorded in the mid-infrared range of $4000-600 \mathrm{~cm}^{-1}$ on bulk canola root samples, which may be used as a clubroot resistance finger-print region for Rcr 1 . It is hypothesized that additional finger-print regions may be identified with other $C R$ genes if different resistance mechanisms are involved.

\section{Materials and Methods}

\subsection{Plant Materials}

An $\mathrm{F}_{1}$ population was developed by crossing the pakchoy (B. rapa ssp. chinensis) cv. Flower Nabana (Evergreen Y.H. Enterprises, Anahein, CA, USA), highly resistant to each of the five pathotypes of P. brassicae found in Canada [16], with a doubled haploid (DH) self-compatible susceptible canola (B. rapa) line developed at AAFC Saskatoon by using the protocol described previously [11,71]. Seeds were sown in the Sunshine \#3 soil-less potting mix (SunGro Horticulture, Vancouver, BC, Canada) in tall plastic cones (5-cm diam., 20-cm tall) called "conetainers" (Steuwe\& Sons, Corvalis, OR, USA), and plants were transplanted later into the same growth medium in 15-cm-diam. pots (1 plant/pot) at 5 about weeks after seeding. The planting mix was amended with $1 \%(w / v)$ 16-8-12 (N-P-K) control-released fertilizer, and all of the plants were kept in a growth room at $23 / 20^{\circ} \mathrm{C}$ (day/night) with a 14-h photoperiod $\left(512 \mu \mathrm{mol} / \mathrm{m}^{2} / \mathrm{s}\right)$.

\subsection{Pathogen Inoculum and Plant Inoculation}

A field population of $P$. brassicae, consisting primarily of the predominant pathotype 3 , was used for inoculation throughout the study. Mature clubroot galls filled with pathogen resting spores were dried at room temperature and stored at $-20^{\circ} \mathrm{C}$ until use. The inoculum was prepared as a 
resting-spore suspension using the method described previously [57], with the concentration adjusted to $1 \times 10^{7}$ spores $/ \mathrm{mL}$. For inoculation, $5 \mathrm{~mL}$ of a resting-spore suspension were applied around the seed to result in about $1 \times 10^{6}$ spores/g growth medium near the root zone. Inoculated plants were kept in the growth room and watered daily to maintain near-saturation soil moisture for two weeks to facilitate infection [72].

\subsection{Root Sampling}

Root samples were collected at 15 days post inoculation (dpi), when secondary infection is generally established in cortical tissue but clubbing symptoms are still not observed [73]. Samples were rinsed with tap water, and separated into inoculated susceptible $(\mathrm{S}-\mathrm{Pb})$ and resistant $(\mathrm{R}-\mathrm{Pb})$ groups based on the detection of Rcr 1 with the markers MS1-3 (5'-AAAACAAATATCCACCACG-3' and 5'-CTCAATCCC-ACAAACCTG-3') and A3-028 (5'-GAGGCCTCCTTTTCTGGTTT-3' and 5'-CCGG AGAA-GTTT-GATTCGAG-3'). These markers are located at 24.02 and $25.36 \mathrm{Mb}$, respectively, on the chromosome A03 [11]. The effectiveness of these markers has been verified previously [11], and only the samples carrying Rcr1 confirmed with both markers were kept for further testing. Non-inoculated susceptible (S-Ck) and resistant (R-Ck) roots were used as controls. The roots of nine random plants from each group were pooled as a biological replicate, with three replicates used for each group.

\subsection{FTIR Spectroscopic Analysis}

All of the infrared data were collected on a mid-infrared beamline (Canadian Light Source Inc., Saskatoon, SK, Canada) using the globar (silicon carbide) as the infrared source. The Bruker-IFS 66V/S spectrophotometer (Bruker Optics, Ettlingen, Germany) fitted with a deuteratedtriglycine sulphate (DTGS) detector was used for FTIR measurements. Root samples of S-Ck, R-Ck, S-Pb, and R-Pb were prepared using the protocol described earlier [ 45 with slight modifications. Root samples were dehydrated in a vacuum freeze drier (Labconco, Kansas City, MO, USA) and ground into fine powders with a mortar and pestle. Approximately $2 \mathrm{mg}$ of freeze dried powder were homogenized with $0.93 \mathrm{~g}$ of dry potassium bromide $(\mathrm{KBr})$ with a mortar and pestle, and made into a pellet under 8-ton pressure using a hydraulic press (Manual hydraulic press 15 Ton, Specac, Orpington, UK). Infrared spectrum was obtained in a transmission mode from each pellet, with $\mathrm{KBr}$ alone used as a background. Each IR spectrum was recorded in the mid infrared range of $4000-600 \mathrm{~cm}^{-1}$ wavenumbers at a spectral resolution of $2 \mathrm{~cm}^{-1}$. For each sample, the spectrum value was an average over 64 scans against the background spectrum value ( $\mathrm{KBr}$ alone, 128 scans). Baseline correction was applied to each normalized spectrum using a rubber-band correction (64 points) and vectors normalized using the OPUS software (version 7.0, Bruker Optics Inc., Billerica, MA, USA). All FTIR spectra reported were averaged over two replicates (measurements of 10 pellets per replicate). The FTIR peaks reported in Table 1 were determined using the Quick Peaks routine in OriginPro with local max settings at $0 \%$ threshold height, no baseline, and the area at $Y=0$ [34].

A second derivative was applied to the spectra to compare $R$ and $S$ samples and evaluate the effect of infection on the composition of the cell wall. The integrated absorption band area was determined using the OPUS integration method C [34]. The secondary protein structure of both R and S with/out inoculation was assessed following the protocol described by Lahlali et al. [34]. The Statistical Analysis System (SAS Institute, Cary, NC, USA) was used for data analysis. Analysis of Variance (ANOVA) and Least Significant Difference (LSD) were used to determine differences between inoculated and non-inoculated samples at $p \leq 0.05$. Raw spectral data were imported into the Unscrambler software (Version 10.1; CAMO Software AS, Oslo, Norway) to extract the possible differences between R and S. Before the principal component analysis (PCA), spectral data were subjected to Multiplicative Scattering Correction (EMSC) and second derivatives to Goly-Savitzky algorithm using nine smoothing points [33]. PCA was performed on all datasets with each FTIR wavelength considered as an equally weighted variable [33]. 


\subsection{Transcription of Cell-Wall and Lignin-Related Genes in Canola Root Samples}

The objective of this experiment was to assess the transcriptional levels of selected genes involved in lignin biosynthetic pathways [Phenylalanine ammonialyase (BrPAL1, BrPAL2 and $B r P A L 3)$, 4-coumarate (CoA ligase- $B r 4 C L$ and cinnamate-4-hydroxylase- $B r C 4 H$ ), hydroxycinnamoyl (cinnamyl alcohol dehydrogenase- $B r C A D$, and cinnamoyl-CoA reductase- $B r C C R$ ), as well as other genes involved in cell wall metabolism (Glutathione-S-transferase-BrGST and Xyloglucanendo -transglycosylate-BrXTH) induced by the P. brassicae inoculation (Table S2) using a StepOne ${ }^{\circledR}$ Plus quantitative RT-PCR (qPCR) system (Life Technologies, Mississauga, ON, Canada). RNA samples from both inoculated and non-inoculated roots were prepared, as described earlier [6]. Complementary DNA was synthesized using the Invitrogen Super Script III First-strand Synthesis system from $1 \mu \mathrm{g}$ of total RNA, and PCR conducted using the Power SYBR green master mix (Life Technologies) following manufacturer's instruction. Cycling conditions were $95^{\circ} \mathrm{C}$ for the initial $10 \mathrm{~min}$ followed by 40 cycles of $15 \mathrm{~s}$ at $95^{\circ} \mathrm{C}, 30 \mathrm{~s}$ at $50^{\circ} \mathrm{C}$, and finally $30 \mathrm{~s}$ at $60^{\circ} \mathrm{C}$.Melt-curve profiling and agarose gel electrophoresis were conducted to confirm the specificity of reaction and the absence of primer dimers. The actin gene Bra037560 was used as an endogenous control to normalize the expression level of target genes for its consistent level of expression among samples. The relative expression data were analysed using the StepOne ${ }^{\circledR}$ software V2.2.2 (Life Technologies).The whole transcription experiment was run twice (two biological replicates), with three technical replicates for each of the sample groups in a repetition. ANOVA and LSD $(p<0.01)$ were performed using the software Statistical Product and Service Solutions (V20.0; IBM, Markham, ON, Canada) for transcription quantity with each of the genes examined.

\section{Conclusions}

The current study characterized several biochemical and molecular changes in canola roots associated with the CR gene Rcr1 in response to clubroot infection using FTIR and qPCR analyses. The most relevant changes appear to be related to the increased biosynthesis of lignin and phenolic rings. These results were generally in agreement with the transcriptome data published previously on the higher expression of genes encoded for callose deposition. The up-regulation of PAL is indicative of an inducible defence response by Rcr1; the activation of a basal defence gene like BrPAL1 through the phenylpropanoid pathway, and lignin accumulation may contribute to the clubroot resistance. The FTIR data indicate that cell-wall components may play a role in defence responses against clubroot mediated by Rcr1. This work also shows the value of using FTIR spectroscopy in conjunction with molecular tools in studying plant-pathogen interactions.

Supplementary Materials: Supplementary materials can be found at www.mdpi.com/1422-0067/18/10/2058/s1.

Acknowledgments: This research was supported partially by funding from SaskCanola (grant\# PRO-7022) and the Canola Agra-Science Cluster-3.1 (Growing Forward II) coordinated by Canola Council of Canada. The funders had no role in study design, data collection, analysis and decision to publish or preparation of manuscript. Part of the research described in this paper was performed at the Canadian Light Source, which is supported by the Canada Foundation for Innovation, Natural Sciences and Engineering Research Council of Canada, the University of Saskatchewan, the Government of Saskatchewan, Western Economic Diversification Canada, the National Research Council Canada, and the Canadian Institutes of Health Research.

Author Contributions: Gary Peng conceived concept of study and obtained funding. Rachid Lahlali, Tao Song, Gary Peng, Mingguang Chu, and Fengqun Yu designed the experiments. Tao Song and Rachid Lahlali performed the experiments. Rachid Lahlali, Tao Song, Saroj Kumar and Chithra Karunakaran analysed the data. Rachid Lahlali, Tao Song and Gary Peng developed the manuscript. All authors reviewed, commented and approved the manuscript for submission.

Conflicts of Interest: The authors declare no conflict of interest. The founding sponsors had no role in the design of the study; in the collection, analyses, or interpretation of data; in the writing of the manuscript, and in the decision to publish the results. 


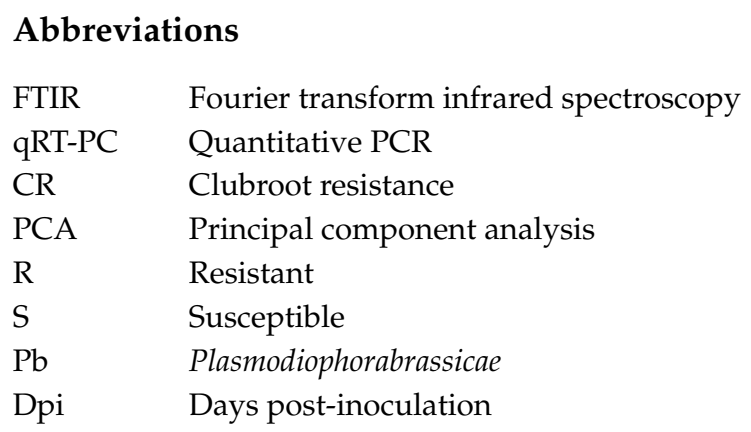

\section{References}

1. Dixon, G.R. The occurrence and economic impact of Plasmodiophorabrassicae and clubroot disease. J. Plant Growth Regul. 2009, 28, 194-202. [CrossRef]

2. Howard, R.J.; Strelkov, S.E.; Harding, M.W. Clubroot of cruciferous crops-New perspectives on an old disease. Can. J. Plant Pathol. Rev. Can. Phytopathol. 2010, 32, 43-57. [CrossRef]

3. Donald, C.; Porter, I. Integrated control of clubroot. J. Plant Growth Regul. 2009, 28, 289-303. [CrossRef]

4. Hirai, M. Genetic analysis of clubroot resistance in Brassica crops. Breed. Sci. 2006, 56, 223-229. [CrossRef]

5. Voorrips, R.E.; Jongerius, M.C.; Kanne, H.J. Mapping of two genes for resistance to clubroot (Plasmodiophorabrassicae) in a population of doubled haploid lines of Brassica oleracea by means of RFLP and AFLP markers. Theor. Appl. Genet. 1997, 94, 75-82. [CrossRef] [PubMed]

6. Werner, S.; Diederichsen, E.; Frauen, M.; Schondelmaier, J.; Jung, C. Genetic mapping of clubroot resistance genes in oilseed rape. Theor. Appl. Genet. 2008, 116, 363-372. [CrossRef] [PubMed]

7. Hirai, M.; Harada, T.; Kubo, N.; Tsukada, M.; Suwabe, K.; Matsumoto, S. A novel locus for clubroot resistance in Brassica rapa and its linkage markers. Theor. Appl. Genet. 2004, 108, 639-643. [CrossRef] [PubMed]

8. Suwabe, K.; Tsukazaki, H.; Iketani, H.; Hatakeyama, K.; Fujimura, M.; Nunome, T.; Fukuoka, H.; Matsumoto, S.; Hirai, M. Identification of two loci for resistance to clubroot (Plasmodiophorabrassicae Woronin) in Brassica rapa L. Theor. Appl. Genet. 2003, 107, 997-1002. [CrossRef] [PubMed]

9. Sakamoto, K.; Saito, A.; Hayashida, N.; Taguchi, G.; Matsumoto, E. Mapping of isolate-specific QTLs for clubroot resistance in Chinese cabbage (Brassica rapa L. ssppekinensis). Theor. Appl. Genet. 2008, 117, 759-767. [CrossRef] [PubMed]

10. Ueno, H.; Matsumoto, E.; Aruga, D.; Kitagawa, S.; Matsumura, H.; Hayashida, N. Molecular characterization of the CRa gene conferring clubroot resistance in Brassica rapa. Plant Mol. Biol. 2012, 80, 621-629. [CrossRef] [PubMed]

11. Chu, M.G.; Song, T.; Falk, K.C.; Zhang, X.G.; Liu, X.J.; Chang, A.; Lahlali, R.; McGregor, L.; Gossen, B.D.; Peng, G.; et al. Fine mapping of Rcr1 and analyses of its effect on transcriptome patterns during infection by Plasmodiophorabrassicae. BMC Genom. 2014, 15. [CrossRef] [PubMed]

12. Diederichsen, E.; Frauen, M.; Linders, E.G.A.; Hatakeyama, K.; Hirai, M. Status and perspectives of clubroot resistance breeding in crucifer crops. J. Plant Growth Regul. 2009, 28, 265-281. [CrossRef]

13. Bradshaw, J.E.; Gemmell, D.J.; Wilson, R.N. Transfer of resistance to clubroot (Plasmodiophorabrassicae) to swedes (Brassica napus L. varnapobrassicaPeterm) from B-rapa. Ann. Appl. Biol. 1997, 130, 337-348. [CrossRef]

14. Piao, Z.Y.; Ramchiary, N.; Lim, Y.P. Genetics of clubroot resistance in brassica species. J. Plant Growth Regul. 2009, 28, 252-264. [CrossRef]

15. Rahman, H.; Peng, G.; Yu, F.; Falk, K.C.; Kulkarni, M.; Selvaraj, G. Genetics and breeding for clubroot resistance in Canadian spring canola (Brassica napus L.). Can. J. Plant Pathol. 2014, 36, 122-134. [CrossRef]

16. Peng, G.; Falk, K.C.; Gugel, R.K.; Franke, C.; Yu, F.Q.; James, B.; Strelkov, S.E.; Hwang, S.F.; McGregor, L. Sources of resistance to Plasmodiophorabrassicae (clubroot) pathotypes virulent on canola. Can. J. Plant Pathol. 2014, 36, 89-99. [CrossRef]

17. Matsumoto, E.; Ueno, H.; Aruga, D.; Sakamoto, K.; Hayashida, N. Accumulation of Three clubroot resistance genes through marker-assisted selection in Chinese cabbage (Brassica rapa ssp. pekinensis). J. Jpn. Soc. Hortic. Sci. 2012, 81, 184-190. [CrossRef] 
18. Strelkov, S.E.; Hwang, S.F.; Manolii, V.P.; Cao, T.; Feindel, D. Emergence of new virulence phenotypes of Plasmodiophorabrassicae on canola (Brassica napus) in Alberta, Canada. Eur. J. Plant Pathol. 2016, 145, 517-529. [CrossRef]

19. Fuchs, H.; Sacristan, M.D. Identification of a gene in Arabidopsis thaliana controlling resistance to clubroot (Plasmodiophorabrassicae) and characterization of the resistance response. Mol. Plant Microbe Interact. 1996, 9, 91-97. [CrossRef]

20. Jubault, M.; Hamon, C.; Gravot, A.; Lariagon, C.; Delourme, R.; Bouchereau, A.; Manzanares-Dauleux, M.J. Differential regulation of root arginine catabolism and polyamine metabolism in clubroot-susceptible and partially resistant Arabidopsis genotypes. Plant Physiol. 2008, 146, 2008-2019. [CrossRef] [PubMed]

21. Kumar, S.; Lahlali, R.; Liu, X.; Karunakaran, C. Infrared spectroscopy combined with imaging a new developing analytical tool in health and plant science. Appl. Spectrosc. Rev. 2016, 51, 466-483. [CrossRef]

22. Conrad, A.O.; Bonello, P. Application of infrared and raman spectroscopy for the identification of disease resistant trees. Front. Plant Sci. 2016, 6. [CrossRef] [PubMed]

23. Griffiths, P.R.; de Haseth, J.A. Fourier Transform Infrared Spectrometry, 2nd ed.; John Wiley \& Sons: Hoboken, NJ, USA, 1986.

24. McCann, M.C.; Chen, L.; Roberts, K.; Kemsley, E.K.; Sene, C.; Carpita, N.C.; Stacey, N.J.; Wilson, R.H. Infrared microspectroscopy: Sampling heterogeneity in plant cell wall composition and architecture. Physiol. Plant. 1997, 100, 729-738. [CrossRef]

25. Mccann, M.C.; Hammouri, M.; Wilson, R.; Belton, P.; Roberts, K. Fourier-transform infrared microspectroscopy is a new way to look at plant-cell walls. Plant Physiol. 1992, 100, 1940-1947. [CrossRef] [PubMed]

26. Gorzsas, A.; Stenlund, H.; Persson, P.; Trygg, J.; Sundberg, B. Cell-specific chemotyping and multivariate imaging by combined FT-IR microspectroscopy and orthogonal projections to latent structures (OPLS) analysis reveals the chemical landscape of secondary xylem. Plant J. 2011, 66, 903-914. [CrossRef] [PubMed]

27. Mazurek, S.; Mucciolo, A.; Humbel, B.M.; Nawrath, C. Transmission fourier transform infrared microspectroscopy allows simultaneous assessment of cutin and cell-wall polysaccharides of Arabidopsis petals. Plant J. 2013, 74, 880-891. [CrossRef] [PubMed]

28. Yee, N.; Benning, L.G.; Phoenix, V.R.; Ferris, F.G. Characterization of metal-cyanobacteria sorption reactions: A combined macroscopic and infrared spectroscopic investigation. Environ. Sci. Technol. 2004, 38, 775-782. [CrossRef] [PubMed]

29. Stuart, B. Biological Applications of Infrared Spectroscopy; John Wiley \& Sons: Chichester, UK, 1997.

30. Dumas, P.; Miller, L. The use of synchrotron infrared microspectroscopy in biological and biomedical investigations. Vib. Spectrosc. 2003, 32, 3-21. [CrossRef]

31. Hawkins, S.A.; Park, B.; Poole, G.H.; Gottwald, T.R.; Windham, W.R.; Albano, J.; Lawrence, K.C. Comparison of FTIR spectra between huanglongbing (citrus greening) and other citrus maladies. J. Agric. Food Chem. 2010, 58, 6007-6010. [CrossRef] [PubMed]

32. Martin, J.A.; Solla, A.; Woodward, S.; Gil, L. Fourier transform-infrared spectroscopy as a new method for evaluating host resistance in the Dutch elm disease complex. Tree Physiol. 2005, 25, 1331-1338. [CrossRef] [PubMed]

33. Dorado, J.; Almendros, G.; Field, J.A.; Sierra-Alvarez, R. Infrared spectroscopy analysis of hemp (Cannabis sativa) after selective delignification by Bjerkanderasp at different nitrogen levels. Enzyme Microb. Technol. 2001, 28, 550-559. [CrossRef]

34. Lahlali, R.; Karunakaran, C.; Wang, L.P.; Willick, I.; Schmidt, M.; Liu, X.; Borondics, F.; Forseille, L.; Fobert, P.R.; Tanino, K.; et al. Synchrotron based phase contrast X-ray imaging combined with FTIR spectroscopy reveals structural and biomolecular differences in spikelets play a significant role in resistance to Fusarium in wheat. BMC Plant Biol. 2015, 15. [CrossRef] [PubMed]

35. Byler, D.M.; Susi, H. Examination of the secondary structure of proteins by DeconvolvedFtir spectra. Biopolymers 1986, 25, 469-487. [CrossRef] [PubMed]

36. Shadle, G.L.; Wesley, S.V.; Korth, K.L.; Chen, F.; Lamb, C.; Dixon, R.A. Phenylpropanoid compounds and disease resistance in transgenic tobacco with altered expression of L-phenylalanine ammonia-lyase. Phytochemistry 2003, 64, 153-161. [CrossRef]

37. Barber, M.S.; Mitchell, H.J. Regulation of phenylpropanoid metabolism in relation to lignin biosynthesis in plants. Int. Rev. Cytol. 1997, 172, 243-293. 
38. Douglas, C.J. Phenylpropanoid metabolism and lignin biosynthesis: From weeds to trees. Trends Plant Sci. 1996, 1, 171-178. [CrossRef]

39. Fischer, G.; Braun, S.; Thissen, R.; Dott, W. FT-IR spectroscopy as a tool for rapid identification and intra-species characterization of airborne filamentous fungi. J. Microbiol. Methods 2006, 64, 63-77. [CrossRef] [PubMed]

40. Wolkers, W.F.; Oliver, A.E.; Tablin, F.; Crowe, J.H. A fourier-transform infrared spectroscopy study of sugar glasses. Carbohydr. Res. 2004, 339, 1077-1085. [CrossRef] [PubMed]

41. Cozzolino, D. Use of infrared spectroscopy for in-field measurement and phenotyping of plant Properties: Instrumentation, data analysis, and examples. Appl. Spectrosc. Rev. 2014, 49, 564-584. [CrossRef]

42. Li, L.; Zhang, Q.; Huang, D.F. A review of imaging techniques for plant phenotyping. Sensors 2014, 14, 20078-20111. [CrossRef] [PubMed]

43. Martin, J.A.; Solla, A.; Woodward, S.; Gil, L. Detection of differential changes in lignin composition of elm xylem tissues inoculated with Ophiostoma novo-ulmi using fourier transform-infrared spectroscopy. For. Pathol. 2007, 37, 187-191. [CrossRef]

44. Kacurakova, M.; Capek, P.; Sasinkova, V.; Wellner, N.; Ebringerova, A. FT-IR study of plant cell wall model compounds: Pectic polysaccharides and hemicelluloses. Carbohydr. Polym. 2000, 43, 195-203. [CrossRef]

45. Lahlali, R.; Jiang, Y.F.; Kumar, S.; Karunakaran, C.; Liu, X.; Borondics, F.; Hallin, E.; Bueckert, R. ATR-FTIR spectroscopy reveals involvement of lipids and proteins of intact pea pollen grains to heat stress tolerance. Front. Plant Sci. 2014, 5. [CrossRef] [PubMed]

46. Martin, J.A.; Solla, A.; Coimbra, M.A.; Gil, L. Metabolic fingerprinting allows discrimination between Ulmuspumila and U-minor, and between U-minor clones of different susceptibility to Dutch elm disease. For. Pathol. 2008, 38, 244-256. [CrossRef]

47. Hardoim, P.R.; Guerrada, R.; Costa, A.M.R.; Serrano, M.S.; Sánchez, M.E.; Coelho, A.C. Temporal metabolic profiling of the Quercussuber-Phytophthoracinnamomi system by middle-infrared spectroscopy. For. Pathol. 2016, 46, 122-133. [CrossRef]

48. Conrad, A.O.; Rodriguez-Saona, L.E.; McPherson, B.A.; Wood, D.L.; Bonello, P. Identification of Quercusagrifolia (coast live oak) resistant to the invasive pathogen Phytophthoraramorum in native stands using Fourier-transform infrared (FT-IR) spectroscopy. Front. Plant Sci. 2014, 5. [CrossRef] [PubMed]

49. Selvendran, R.R. Analysis of cell-wall material from plant-Tissues-Extraction and purification. Phytochemistry 1975, 14, 1011-1017. [CrossRef]

50. York, W.S.; Darvill, A.G.; Mcneil, M.; Stevenson, T.T.; Albersheim, P. Isolation and characterization of plant-cell walls and cell-wall components. Methods Enzymol. 1986, 118, 3-40.

51. Kircher, M.; Kelso, J. High-throughput DNA sequencing-Concepts and limitations. Bioessays 2010, 32, 524-536. [CrossRef] [PubMed]

52. Mitchell, H.J.; Hall, S.A.; Stratford, R.; Hall, J.L.; Barber, M.S. Differential induction of cinnamyl alcohol dehydrogenase during defensive lignification in wheat (Triticumaestivum L.): Characterisation of the major inducible form. Planta 1999, 208, 31-37. [CrossRef]

53. MauchMani, B.; Slusarenko, A.J. Production of salicylic acid precursors is a major function of phenylalanine ammonia-lyase in the resistance of arabidopsis to Peronosporaparasitica. Plant Cell 1996, 8, $203-212$. [CrossRef] [PubMed]

54. Zhao, X.Y.; Zhu, D.F.; Zhou, B.; Peng, W.S.; Lin, J.Z.; Huang, X.Q.; He, R.Q.; Zhuo, Y.H.; Peng, D.; Tang, D.Y.; et al. Over-expression of the AtGA2ox8 gene decreases the biomass accumulation and lignification in rapeseed (Brassica napus L.). J. Zhejiang Univ. Sci. B 2010, 11, 471-481. [CrossRef] [PubMed]

55. Devos, S.; Vissenberg, K.; Verbelen, J.P.; Prinsen, E. Infection of Chinese cabbage by Plasmodiophorabrassicae leads to a stimulation of plant growth: Impacts on cell wall metabolism and hormone balance. New Phytol. 2005, 166, 241-250. [CrossRef] [PubMed]

56. Verbelen, J.P.; Vissenberg, K.; Kerstens, S.; Le, J. Cell expansion in the epidermis: Microtubules, cellulose orientation and wall loosening enzymes. J. Plant Physiol. 2001, 158, 537-543. [CrossRef]

57. Lahlali, R.; McGregor, L.; Song, T.; Gossen, B.D.; Narisawa, K.; Peng, G. Heteroconiumchaetospira induces resistance to clubroot via upregulation of host genes involved in jasmonic acid, ethylene, and auxin biosynthesis. PLoS ONE 2014, 9. [CrossRef] [PubMed]

58. Lahlali, R.; Peng, G. Suppression of clubroot by Clonostachysrosea via antibiosis and induced host resistance. Plant Pathol. 2014, 63, 447-455. [CrossRef] 
59. Frova, C. Glutathione transferases in the genomics era: New insights and perspectives. Biomol. Eng. 2006, 23, 149-169. [CrossRef] [PubMed]

60. Jain, M.; Ghanashyam, C.; Bhattacharjee, A. Comprehensive expression analysis suggests overlapping and specific roles of rice glutathione S-transferase genes during development and stress responses. BMC Genom. 2010, 11. [CrossRef] [PubMed]

61. Olsztyńska-Janus, S.; Gąsior-Głogowska, M.; Szymborska-Małek, K.; Czarnik-Matusewicz, B.; Komorowska, M. Specific application of vibrational spectroscopy in biomedical engineering. In Biomedical Engineering, Trends, Research and Technologies; Komorowska, M., Olsztynska-Janus, S., Eds.; In-Tech: Shanghai, China, 2011; pp. 91-120.

62. Peng, G.; Lahlali, R.; Hwang, S.F.; Pageau, D.; Hynes, R.K.; Mcdonald, M.R.; Gossen, B.D.; Strelkov, S.E. Special Issue: Crop rotation, cultivar resistance, and fungicides/biofungicides for managing clubroot (Plasmodiophorabrassicae) on canola. Can. J. Plant Pathol. 2014, 36, 99-112. [CrossRef]

63. Lahlali, R.; Peng, G.; McGregor, L.; Gossen, B.D.; Hwang, S.F.; McDonald, M. Mechanisms of the biofungicide Serenade (Bacillus subtilis QST713) in suppressing clubroot. Biocontrol Sci. Technol. 2011, 21, 1351-1362. [CrossRef]

64. Nafisi, M.; Fimognari, L.; Sakuragi, Y. Interplays between the cell wall and phytohormones in interaction between plants and necrotrophic pathogens. Phytochemistry 2015, 112, 63-71. [CrossRef] [PubMed]

65. Voigt, C.A. Callose-mediated resistance to pathogenic intruders in plant defense-related papillae. Front. Plant Sci. 2014, 5. [CrossRef] [PubMed]

66. Zhao, Q.; Dixon, R.A. Altering the cell wall and its impact on plant disease: From forage to bioenergy. Annu. Rev. Phytopathol. 2014, 52, 69-91. [CrossRef] [PubMed]

67. Luna, E.; Pastor, V.; Robert, J.; Flors, V.; Mauch-Mani, B.; Ton, J. Callose deposition: A multifaceted plant defense response. Mol. Plant Microbe Interact. 2011, 24, 183-193. [CrossRef] [PubMed]

68. Bradley, D.J.; Kjellbom, P.; Lamb, C.J. Elicitor-induced and wound-induced oxidative cross-linking of a proline-rich plant-cell wall protein-A novel, rapid defense response. Cell 1992, 70, 21-30. [CrossRef]

69. O'Brien, J.A.; Daudi, A.; Finch, P.; Butt, V.S.; Whitelegge, J.P.; Souda, P.; Ausubel, F.M.; Bolwell, G.P. A peroxidase-dependent apoplastic oxidative burst in cultured arabidopsis cells functions in MAMP-elicited defense. Plant Physiol. 2012, 158, 2013-2027. [CrossRef] [PubMed]

70. Strelkov, S.E.; Manolii, V.P.; Cao, T.; Xue, S.; Hwang, S.F. Pathotype classification of Plasmodiophorabrassicae and its occurrence in Brassica napus in Alberta, Canada. J. Phytopathol. 2007, 155, 706-712. [CrossRef]

71. Lahlali, R.; Peng, G.; Gossen, B.D.; McGregor, L.; Yu, F.Q.; Hynes, R.K.; Hwang, S.F.; McDonald, M.R.; Boyetchko, S.M. Evidence that the biofungicide serenade (Bacillus subtilis) suppresses clubroot on canola via antibiosis and induced host resistance. Phytopathology 2013, 103, 245-254. [CrossRef] [PubMed]

72. Peng, G.; McGregor, L.; Lahlali, R.; Gossen, B.D.; Hwang, S.F.; Adhikari, K.K.; Strelkov, S.E.; McDonald, M.R. Potential biological control of clubroot on canola and crucifer vegetable crops. Plant Pathol. 2011, 60, 566-574. [CrossRef]

73. Mcdonald, M.; Sharma, K.; Nieuwelaar, A.V.; Gossen, B.D. A comparison of clubroot resistance in Brassica vegetable crops. Phytopathology 2012, 102, 78.

(c) 2017 by the authors. Licensee MDPI, Basel, Switzerland. This article is an open access article distributed under the terms and conditions of the Creative Commons Attribution (CC BY) license (http:/ / creativecommons.org/licenses/by/4.0/). 